\title{
STRATEGI PEMBIAYAAN PENDIDIKAN DASAR DAN MENENGAH DI ERA PANDEMI COVID-19
}

\author{
Marinu Waruwu \\ Universitas Kristen Satya Wacana \\ email: marinu.waruwu@uksw.edu
}

\begin{abstract}
ABSTRACK
The objective of this study is to examine the strategy of financing education in private schools. Based on research conducted by researcher, studies on education financing strategies during the Covid-19 pandemic have not been widely carried out. The research method was conducted through literature studies from national and international journals, government policy documents, and books. Data analysis used qualitative descriptive approach. The results of the study show that the strategy of financing education during the Covid 19 pandemic mostly goes well with the policy alignments from the government through internet data quota assistance, affirmation and performance School Operational Assistance, scholarships, wage subsidies, and Single Tuition in universities. However, there are several schools, especially private schools that have difficulty paying teacher's salary, teacher welfare declines, and parents who are late paying educational management contribution. The strategy for education financing solutions during the COVID-19 pandemic is that government policies in the form of assistance to students and parents need to be continued, consistency of budget planning by schools, use of budgets that prioritize priority scales, and transparency and accountability in the management of education financing.
\end{abstract}

Keywords: Strategy; financing; education, studies; literature, solutions

\begin{abstract}
ABSTRAK
Tujuan penelitian ini adalah untuk mengkaji strategi pembiayaan pendidikan di sekolah swasta. Berdasarkan riset yang dilakukan peneliti, kajian tentang strategi pembiayaan pendidikan pada masa pandemi Covid 19 belum banyak dilakukan. Metode penelitian dilakukan melalui studi literatur dari jurnal nasional maupun internasional, dokumen kebijakan pemerintah, dan buku. Analisa data dengan pendekatan deskriptif kualitatif. Hasil penelitian menunjukkan bahwa strategi pembiayaan pendidikan pada masa pandemi Covid 19 sebagian besar berjalan dengan baik dengan adanya keberpihakan kebijakan dari pemerintahan melalui bantuan kuota internet, bantuan BOS afirmasi dan kinerja, beasiswa, subsidi upah, dan UKT di perguruan tinggi. Namun demikian, masih terdapat sekolah khususnya sekolah swasta mengalami kesulitan membayar honorarium guru, kesejahteraan guru menurun, dan pembayaran SPP oleh orang tua kurang lancar. Strategi solusi pembiayaan pendidikan pada masa pandemi Covid 19 adalah kebijakan pemerintah berupa bantuan kepada peserta didik dan orang tua perlu terus dilanjutkan, konsistensi perencanaan anggaran oleh sekolah, penggunaan anggaran yang mengedepankan skala prioritas, dan adanya transparansi dan akuntabilitas dalam pengelolaan pembiayaan pendidikan.
\end{abstract}

Kata Kunci: Strategi; pembiayaan; pendidikan; studi; literatur, solusi 


\section{PENDAHULUAN}

Pandemi Covid 19 memberikan dampak signifikan pada berbagai bidang kehidupan. Dampak Covid 19 paling dirasakan pada bidang ekonomi, pendidikan, kesehatan dan sosial. Dampak pada bidang ekonomi seperti adanya penurunan pendapatan, lapangan pekerjaan terbatas, dan pengeluaran yang kian besar (Sayuti \& Hidayati, 2020). Pada bidang pendidikan tampak pada penutupan Lembaga pendidikan seperti sekolah, pembelajaran dari rumah, penurunan keterampilan (Sobana, 2020). Kemudian pada bidang kesehatan, semakin bertambah jumlah warga terinfeksi virus lalu meninggal. Berbagai dampak tersebut memberikan tekanan nyata bagi eksistensi kehidupan manusia dan keberadaan lembaga pendidikan, kesehatan, ekonomi mengalami tekanan hebat sebagai dampak krisis pandemi Covid 19.

Selama pandemi Covid 19, sekolah dasar dan menengah yang berada dalam naungan Yayasan Pendidikan Swasta mengalami tekanan luar biasa. Sekolah-sekolah tersebut mengalami penurunan jumlah peserta didik. Penurunan jumlah peserta didik berdampak pada penurunan pendapatan sekolah. Sumber pendapatan utama sekolah-sekolah swasta adalah pendanaan dari masyarakat dan orang tua peserta didik. Dengan menurunnya jumlah peserta didik, maka pemasukan berkurang. Sementara pengeluaran sekolah untuk biaya operasional seperti pembayaran gaji guru, biaya fasilitas dan lainnya tetap stabil. Jurang yang terjadi antara pendapatan dengan pengeluaran telah menyebabkan sekolah-sekolah swasta mengalami guncangan dalam pengelolaan pembiayaan pendidikan. Sekolah mengalami kesulitan dalam pembiayaan operasional sekolah. Untuk menyelamatkan eksistensi sekolah, beberapa kebijakan jangka pendek dilakukan seperti memetakan ulang tenaga staf kependidikan, pemotongan gaji pegawai sampai pada pemutusan hubungan kerja.

Dalam menghadapi guncangan pada pembiayaan pendidikan selama pandemi Covid 19, sekolah dasar dan menengah mesti mengevaluasi ulang pengelolaan pembiayaan pendidikan. Evaluasi bertujuan untuk mengetahui kekuatan dan kelemahan, peluang dan ancaman terhadap pengelolaan pembiayaan pendidikan. Hasil evaluasi dijadikan pijakan untuk melakukan perencanaan pembiayaan pendidikan secara komprehensif. Perencanaan pembiayaan mengedepankan pemikiran strategis dan skala prioritas. Program sekolah yang bersifat strategis pada peningkatan mutu pendidikan perlu mendapatkan skala prioritas.

Beberapa sekolah berhasil menata ulang pembiayaan pendidikan selama pandemi Covid 19. Penataan ulang tampak pada perencanaan anggaran dengan mengutamakan skala prioritas. Hal ini sejalan dengan pemikiran (Margareta \& Ismanto, 2017) bahwa strategi pembiayaan sekolah meliputi strategi perencanaan (pelaksanaan gagasan), pelaksanaan, evaluasi, dan tindak lanjut. Maka dibutuhkan orang-orang yang mampu mengelola dana dan merencanakan strategi pembiayaan sampai strategi tindak lanjut pembiayaan. Jika hal ini dilakukan, maka sekolah akan per lahan bangkit dan mampu mengatasi kesulitan yang dihadapi.

Hasil penelitian (Amalia \& Sa'adah, 2020) menemukan bahwa pada masa pandemi Covid 19, sekolah mengalami keterbatasan kemampuan adaptasi seperti penguasaan teknologi, sarana dan pra sarana kurang memadai, akses internet terbatas, dan kurangnya kemauan untuk menganggarkan program sekolah. Hal ini selaras dengan studi pendahuluan peneliti di lapangan bahwa tidak semua sekolah memiliki kecepatan beradaptasi dalam menghadapi dampak pandemi Covid 19. Ada sekolah tertentu yang mengalami keterpurukan baik dari segi pendapatan, mutu lulusan, maupun mutu guru. Jumlah peserta didik menurun drastis, sementara 
pembiayaan di bidang operasional seperti gaji guru dan biaya fasilitas tetap tinggi. Kemudian, perencanaan anggaran belum bersifat strategis dan skala prioritas. Hal demikian terjadi karena kepemimpinan berada di zona nyaman, kurang kreatif dan implementasi kebijakan terkesan rumit dan birokratis, serta sikap pasrah pada keadaan.

Gap yang terjadi antara kondisi ideal dengan hasil studi pendahuluan menunjukkan adanya permasalahan pembiayaan pendidikan selama pandemi Covid 19. Penelitian ini bertujuan untuk mengkaji strategi pembiayaan pendidikan dasar dan menengah melalui studi literatur. Hasil penelitian diharapkan menjadi masukkan bagi sekolah untuk membangun strategi pembiayaan pendidikan di masa pandemi Covid 19.

\section{METODE}

Tujuan penelitian ini adalah untuk mengkaji strategi pembiayaan pendidikan di sekolah dasar dan menengah khususnya sekolah swasta. Berdasarkan riset yang dilakukan peneliti, kajian tentang strategi pembiayaan pendidikan pada masa pandemi Covid 19 belum banyak dilakukan. Metode penelitian dilakukan melalui studi literatur dari jurnal nasional maupun internasional, dokumen kebijakan pemerintah, dan buku-buku yang relevan. Analisa data dengan pendekatan deskriptif kualitatif. Menurut Winartha dalam (Lindawati, 2016) deskriptif kualitatif adalah menganalisis, menggambarkan dan meringkas berbagai kondisi, situasi dari berbagai data yang dikumpulkan berupa wawancara atau pengamatan mengenai masalah yang diteliti.

\section{HASIL DAN PEMBAHASAN}

\section{Pembiayaan Pendidikan Di Era Covid 19}

\section{a. Pengertian}

Pembiayaan pendidikan merupakan salah salah satu pilar penting pada pengelolaan pendidikan. Posisi pembiayaan pendidikan penting karena penyelenggaraan pendidikan berjalan apabila memiliki dana yang dapat menopang secara operasional baik fasilitas maupun sumber daya manusia. Pertimbangan inilah yang menjadikan pembiayaan pendidikan menjadi salah satu standar nasional pendidikan. Pembiayaan pendidikan sebagai standar nasional memiliki urgensi dalam memfasilitasi kegiatan proses pendidikan.

Beberapa pengertian tentang pembiayaan pendidikan. Salah satunya diungkapkan Supriadi dalam (Suhirman, 2012), bahwa pembiayaan pendidikan merupakan salah satu komponen masukkan yang sangat penting dalam pengelolaan pendidikan. Pembiayaan pendidikan berusaha memfasilitasi pelaksanaan kebijakan program sekolah, keterlaksanaan kegiatan dan dampaknya pada pengembangan sekolah yang bermutu.

Pandangan lain diungkapkan Fattah dalam (Ade Sopiali, 2018). Menurutnya pembiayaan pendidikan adalah jumlah uang yang dihasilkan dan dibelanjakan untuk operasionalitas pendidikan seperti gaji guru, fasilitas, pengadaan perangkat pendidikan, kegiatan ekstrakurikuler, kegiatan pengelolaan dan supervisi pendidikan. Adapun menurut Levin dalam (Fironika K, 2015), pembiayaan pendidikan merupakan proses di mana pendapatan dan sumber 
daya yang ada digunakan untuk operasional sekolah di berbagai tempat dan jenjang pendidikan yang berbeda-beda.

Berdasarkan berbagai pandangan tersebut di atas, maka dapat ditarik kesimpulan bahwa pembiayaan pendidikan merupakan jumlah uang yang didapatkan melalui pendapatan dan sumber daya dan digunakan untuk memfasilitasi terlaksananya operasional sekolah seperti program sekolah, gaji guru, fasilitas, dan berbagai kebutuhan sekolah lainnya.

\section{b. Standar Pembiayaan Pendidikan}

Pengelolaan pendidikan memiliki standar minimum. Standar minimum perlu agar setiap institusi pendidikan atau unit sekolah mampu mengelola dirinya secara mandiri. Apabila sekolah sudah mampu mengelola dirinya secara mandiri otomatis pelaksanaan proses pembelajaran berlangsung dengan baik dan lancar tanpa mengalami hambatan. Salah satu standar pengelolaan pendidikan nasional adalah standar pembiayaan pendidikan. Standar pembiayaan pendidikan merupakan salah satu standar penting diantara 8 (delapan) standar pengelolaan pendidikan secara nasional.

Peraturan Pemerintahan No.32 tahun 2013 menegaskan bahwa standar pembiayaan pendidikan merupakan kriteria mengenai komponen dan besarnya biaya operasi satuan pendidikan yang berlaku selama satu tahun (Permendiknas, 2013). Penjelasan secara sistematis diungkapkan pada Peraturan Menteri Pendidikan dan Kebudayaan Pasal 32 tahun 2021, standar pembiayaan pendidikan meliputi 1) kriteria minimal mengenai komponen pembiayaan pendidikan pada satuan pendidikan, 2) pembiayaan pendidikan seperti biaya investasi dan operasional, 3) biaya investasi seperti lahan, sarana dan prasarana, penyediaan dan pengembangan sumber daya manusia, dan modal kerja tetap, 4) biaya operasional seperti personalia dan non personalia (Permendikbud, 2021).

Kemudian (Kurniawan, 2019) mengelompokan 4 (empat) bagian pembiayaan pendidikan sebagai berikut. Pertama, biaya langsung yakni pengeluaran yang dilakukan untuk membiayai jalannya proses penyelenggaraan pendidikan, pengajaran, dan pengabdian masyarakat. Biaya langsung termasuk biaya rutin yang digunakan untuk membiayai operasional seperti program sekolah, pembayaran gaji, administrasi, pemeliharaan sarana dan prasarana. Kedua, biaya tidak langsung, yakni pengeluaran yang tidak secara langsung berhubungan dengan proses pendidikan seperti pengeluaran keluarga untuk membiayai anaknya dan biaya dari masyarakat untuk membiayai sekolah. Ketiga, seluruh pembiayaan proses pendidikan dalam bentuk uang baik yang dikeluarkan secara langsung, maupun tidak langsung. Keempat, seluruh pembiayaan proses pendidikan yang tidak dalam bentuk uang yang dikeluarkan baik secara langsung maupun tidak langsung. Menurut (Alawiyah, 2017), biaya personalia meliputi biaya pendidikan yang dikeluarkan peserta didik, sementara biaya operasional meliputi gaji dan tunjangan pendidik dan tenaga kependidikan, pemeliharaan fasilitas pendidikan dan biaya operasional tidak langsung lainnya seperti air, telekomunikasi, konsumsi dan sebagainya.

Berdasarkan beberapa sumber referensi tersebut, peneliti menarik kesimpulan bahwa penetapan standar pembiayaan pendidikan dilakukan berdasarkan tingkat urgenitas pada pengelolaan pendidikan. Biaya pendidikan seperti program sekolah, biaya gaji guru, adminsitrasi dan pemeliharaan sarana dan pra sarana memiliki urgenitas dengan kategori 
tingkat pertama, yang artinya biaya yang dikeluarkan sangat penting dalam proses keterlaksanaan proses pendidikan. Standar pembiayaan pendidikan secara langsung mendapatkan perhatian terutama sumber pembiayaan. Sumber pembiayaan efektif apabila berdampak pada keterlaksanaan proses pembelajaran. Namun keterlaksanaan proses pembelajaran tersendat apabila mengalami kendala pada sumber pembiayaan. Institusi pendidikan khususnya sekolah swasta memiliki tanggung jawab agar sumber pembiayaan pendidikan secara langsung tidak mengalami hambatan. Salah satu strategi yang dilakukan adalah peningkatan mutu. Mutu sekolah yang baik menjadi jaminan daya tarik orang tua dan masyarakat. Sementara jenis pembiayaan lain seperti biaya tidak langsung dan pembiayaan lainnya termasuk dalam kategori urgensi tingkat kedua.

\section{c. Sumber Pembiayaan Pendidikan}

Pembiayaan pendidikan bukan hanya tanggungjawab penyelenggara pendidikan. Sumber pembiayaan pendidikan menjadi tanggung jawab bersama antara pemerintah, masyarakat, orang tua dan pihak-pihak lain yang memiliki perhatian pada pengembangan pendidikan melalui beasiswa. Pemerintah sebagai garda terdepan untuk investasi sumber daya manusia memiliki tanggung jawab besar. Tanggung jawab besar tersebut tampak pada alokasi anggaran pendidikan dalam APBN sebesar 20\% (Tamam, 2018). Selain pemerintah, masyarakat dan orang tua memiliki tanggung jawab seperti pemerintah agar proses pendidikan tetap berjalan sebagaimana mestinya.

Menurut Undang-Undang No. 20 Pasal 46 sumber pembiayaan pendidikan antara lain: penyediaan dana bantuan operasional sekolah (BOS), dana masyarakat yang berasal dari komite sekolah dan orang tua, dana swadaya berupa usaha mandiri sekolah seperti kantin, koperasi dan unit produksi, dan sumber-sumber lain yang menunjang pembiayaan pendidikan (Permendiknas, 2003). Hal ini semakin jelas pada Permendiknas No. 48 tahun 2008 Pasal 50 tentang Pendanaan Pendidikan yang bersumber dari penyelenggaran atau satuan pendidikan bersangkutan, bantuan pemerintah, bantuan pemerintah daerah, pungutan dari peserta didik atau orang tua, bantuan pemangku kepentingan satuan pendidikan di luar peserta didik atau orang tua, bantuan pihak asing yang tidak mengikat, dan sumber-sumber lain yang sah (Permendiknas, 2008).

Berdasarkan kebijakan pemerintahan melalui peraturan perundang-undangan tersebut, sumber pembiayaan memiliki semangat kolaborasi dan semangat gotong royong. Sumber pembiayaan bukan hanya tanggung jawab sekolah atau orang tua. Sebaliknya pengambil kebijakan seperti pemerintah pusat dan daerah ikut hadir melalui bantuan operasional sekolah dan beasiswa.

Kesimpulannya bahwa pembiayaan pendidikan memerlukan kolaborasi dan semangat kerja sama dari berbagai pihak sehingga saling melengkapi dalam menyukseskan proses penyelenggaraan pendidikan. Sekolah-sekolah swasta yang dikelola masyarakat pun mendapatkan perhatian dari pemerintahan melalui dana bantuan operasional, pengembangan fasilitas, pengembangan profesional tenaga kepala sekolah dan guru. Ini adalah tanggungjawab bersama untuk saling melengkapi melakukan investasi besar di bidang sumber daya manusia sekolah. 


\section{d. Dampak Covid 19 pada Pembiayaan Pendidikan}

Pandemi Covid 19 memberikan dampak pada pengelolaan pendidikan. Salah satu dampak yang dirasakan adalah pembiayaan pendidikan dasar dan menengah sekolah swasta. Pandemi Covid 19 memberikan dampak pada menurunnya pendapatan sekolah. Jumlah peserta didik mengalami penurunan sehingga berdampak pada pemasukan sekolah. Hal ini berdampak pada operasional sekolah. Sekolah-sekolah swasta yang mengandalkan pemasukan dari orang tua atau masyarakat mengalami defisit antara pendapatan yang diterima dengan pengeluaran untuk biaya operasional seperti gaji guru dan biaya pengembangan fasilitas lain.

Hasil penelitian (Waliyah et al., 2021) menemukan bahwa pandemi Covid 19 memberikan dampak pada pembiayaan pendidikan di SMK Gazza Wiguna 1. Sekolah mengalami kesulitan untuk membayar honorarium guru akibat banyaknya orang tua peserta didik yang mengalami kesulitan membayar SPP. Kemudian temuan (Aji, 2020) bahwa sekolah kurang siap menghadapi pandemi Covid 19 karena kurangnya anggaran yang tersedia untuk pembayaran fasilitas seperti internet dan kesejahteraan guru.

Lalu penelitian (Masruri et al., 2021) mengungkapkan bahwa pengelolaan keuangan sekolah mengalami ketidakseimbangan antara pendapatan dan pengeluaran karena pembayaran SPP oleh orang tua kurang lancar.

Beberapa hasil penelitian tersebut menunjukkan pengelolaan pendidikan di era pandemi Covid 19 mengalami permasalahan serius. Sekolah mengalami kesulitan dalam hal pembiayaan baik untuk pembayaran honorarium guru maupun perawatan fasilitas pendidikan. Kesulitan ini terjadi karena pendapatan orang tua peserta didik menurun drastis. Hal ini didukung hasil penelitian Lembaga Wahana Visi Indonesia (2020) yang mengungkapkan bahwa 9 dari 10 rumah tangga terdampak oleh Covid 19 dan sekitar $70 \%$ terdampak parah di mana sumber pendapatan menurun drastis (Siantoro et al., 2020). Permasalahan ini memerlukan strategi pembiayaan pendidikan sehingga sekolah tetap menjaga eksistensinya untuk mencerdaskan generasi bangsa.

\section{Strategi Pembiayaan Pendidikan}

\section{a. Keberpihakan Kebijakan}

Pandemi Covid 19 membuat pemerintah dan institusi pendidikan di bawahnya mesti berpikir lebih kreatif mengatasi tantangan pembiayaan pendidikan. Strategi dibutuhkan agar sekolah dapat bertahan di tengah melemahnya ekonomi masyarakat yang berdampak pada pembiayaan pendidikan. Salah satu strategi yang dilakukan adalah keberpihakan kebijakan pemerintah pusat melalui kementerian pendidikan dan kebudayaan. Selama pandemi Covid 19 beberapa kebijakan pusat sungguh dirasakan oleh sekolah seperti kebijakan bantuan internet bagi guru dan peserta didik, kebijakan UKT, kebijakan honor tambahan guru, dan kebijakan bantuan uang tunai kepada orang tua peserta didik melalui kementerian ketenagakerjaan. Kebijakan-kebijakan tersebut sungguh dirasakan oleh peserta didik dan orang tua.

Keberpihakan kebijakan tercermin pada beberapa bantuan pemerintah pusat bagi terdampak Covid 19. Pertama, keringanan UKT. Hal ini diatur dalam Peraturan Menteri Pendidikan dan Kebudayaan Nomor 25 tahun 2020 tentang standar satuan biaya operasional pendidikan tinggi. Peraturan ini bertujuan memberikan keringanan UKT bagi mahasiswa di perguruan tinggi negeri 
yang menghadapi kendala finansial selama pandemi Covid-19. Isi dari Permen tersebut adalah cicilan UKT sesuai kemampuan ekonomi, penundaan UKT, penurunan UKT, beasiswa Kartu Indonesia Pintar, dan bantuan infrastruktur seperti bantuan dana jaringan internet, dan pulsa (Permendikbud, 2020). Kedua, kebijakan bantuan operasional sekolah afirmasi dan kinerja untuk sekolah yang berada di wilayah terpencil dan terbelakang (Permendikbud, 2020) dan sekolah dengan proporsi peserta didik dari keluarga miskin lebih besar, menerima dana BOS Reguler lebih rendah, dan sekolah yang memiliki proporsi guru tidak tetap lebih besar (Permendikbud, 2020). Ketiga, bantuan subsidi kuota internet, subsidi upah bagi tenaga pendidik dan tenaga kependidikan. Ketiga kebijakan pemerintah tersebut memiliki dampak luar biasa pada kelangsungan pendidikan peserta didik dan mahasiswa. Peserta didik dan mahasiswa dapat terus melanjutkan pendidikan karena mendapatkan keberpihakan kebijakan dari pemerintah.

\section{b. Konsistensi Perencanaan Anggaran}

Perencanaan merupakan upaya menetapkan tujuan dan target, merumuskan strategi, menentukan sumber daya yang dibutuhkan dan menetapkan standar atau indikator ketercapaian. Dalam pembiayaan pendidikan, perencanaan anggaran dibutuhkan agar pengeluaran sesuai dengan pemasukkan dan setiap kegiatan berdasarkan kebutuhan sekolah.

Menurut Conyers dan Hills dalam (Kharisma, 2018) perencanaan merupakan suatu proses yang berkesinambungan berkaitan dengan keputusan atau pilihan atas berbagai alternatif untuk mencapai tujuan tertentu pada masa mandatang. Sementara menurut Mardiasmo dalam (Maulan Irwadi, 2015), anggaran merupakan alat perencanaan yang digunakan merumuskan tujuan dan sasaran kebijakan, merencanakan berbagai program dan kegiatan, mengalokasikan dana pada berbagai program dan kegiatan yang telah disusun dan menentukan indikator kinerja dan tingkat ketercapaian strategi.

Berdasarkan kedua definisi tersebut dapat disimpulkan bahwa perencanaan anggaran merupakan suatu proses pengalokasian anggaran berdasarkan berbagai program dan kegiatan yang disusun berdasarkan standar dan indikator ketercapaian.

Pada masa pandemi Covid 19, pembiayaan pendidikan membutuhkan perencanaan anggaran yang konsisten. Sikap konsisten tampak pada perencanaan anggaran kegiatan yang selaras dengan analisis kebutuhan dan adanya upaya menyeimbangkan antara pendapatan dengan pengeluaran. Sikap ini dibangun agar pengelolaan keuangan sekolah lebih efektif dan efisien. Sekolah terhindar dari kebangkrutan akibat kekurangan pendapatan karena menurunnya penghasilan masyarakat.

\section{c. Skala Prioritas}

Pengambil kebijakan sekolah seperti Yayasan, guru dan kepala sekolah serta seluruh stakeholder perlu memikirkan dan mengimplementasikan dalam bentuk kebijakan skala prioritas pembiayaan pendidikan. Skala prioritas membantu pengambil kebijakan mengetahui dan memetakan pembiayaan apa saja yang perlu didahulukan dan yang bisa ditunda atau ditiadakan. 
Menurut (Endrianti, 2016), skala prioritas merupakan upaya untuk menempatkan hal yang lebih penting dibandingkan dengan hal lainnya. Berdasarkan pengertian tersebut maka pengambil kebijakan sekolah perlu memetakan secara detail program apa saja yang menjadi prioritas pembiayaan sekolah. Skala prioritas dimulai sejak tahap perencanaan anggaran sampai pada pelaksanaan.

Pembiayaan pendidikan pada masa pandemi Covid 19 perlu menentukan skala prioritas. Sekolah-sekolah mesti lebih kreatif dan inovatif memikirkan skala prioritas dalam perencanaan pembiayaan sekolah sehingga sekolah mampu melewati situasi sulit pandemi Covid 19. Salah satu strategi yang dilakukan adalah pembiayaan pada program-program strategis seperti biaya operasional pendidikan perlu mendapatkan perhatian lebih serius. Pembiayaan pada program yang bersifat sekunder atau tidak terlalu penting untuk dilakukan dapat ditunda pada pembiayaan tahun berikutnya. Skala prioritas pembiayaan bertujuan menjaga stabilitas pengelolaan sekolah.

\section{d. Transparansi dan Akuntabilitas}

Pengelolaan pembiayaan pendidikan pada masa pandemi Covid 19 membutuhkan transparansi dan akuntabilitas. Pembiayaan pendidikan dilakukan secara terbuka dan transparan dan laporan keuangannya dapat dipertanggungjawabkan. Penerapan prinsip transparansi dan akuntabilitas mendorong kepercayaan publik tetap tinggi walaupun situasi ekonomi masyarakat semakin menurun.

Menurut Lalolo dalam (Adianto Asdi Sangki, Ronny Gosal, 2017) transparansi adalah prinsip yang menjamin akses kebebasan bagi setiap orang untuk mendapatkan informasi pengelolaan kebijakan, pembuatan dan hasil yang dicapai. Sementara akuntabilitas menurut Santoso dalam (Utama, 2014) adalah kewajiban mempertanggungjawabkan keputusan, aktivitas dan kinerja organisasi yang diukur secara objektif dalam bentuk laporan kepada pihak internal maupun eksternal.

Berdasarkan kedua definisi tersebut dapat disimpulkan bahwa penerapan prinsip transparansi dan akuntabilitas pada pembiayaan sekolah bertujuan untuk bersifat terbuka dalam pengambilan setiap keputusan dan mampu mempertanggungjawabkan setiap pembiayaan pendidikan secara akuntabel. Kedua prinsip ini sangat penting dalam membangun kepercayaan publik pada sekolah. Pengelolaan pembiayaan pendidikan juga lebih profesional karena ada pengawasan dari masyarakat luas.

Hasil penelitian (Utama, 2014) menunjukkan bahwa transparansi dan akuntabilitas pengelolaan keuangan sekolah berpengaruh pada kinerja guru. Sementara penelitian (Solihat \& Sugiharto, 2009) menunjukkan bahwa prinsip transparansi dan akuntabilitas berpengaruh positif pada tingkat partisipasi publik khususnya orang tua pada sekolah.

Kajian teori dan hasil penelitian terdahulu menunjukkan bahwa penerapan prinsip transparansi dan akuntabilitas pembiayaan pendidikan pada masa pandemi Covid 19 memiliki dampak positif pada pengelolaan keuangan sekolah. Pembiayaan pendidikan dikelola secara transparan dan kinerjanya dapat dipertanggungjawabkan dihadapan masyarakat. Kepercayaan masyarakat terbangun dengan sendirinya. 


\section{KESIMPULAN}

Pandemi Covid 19 memiliki dampak luar biasa pada pembiayaan pendidikan dasar dan menengah. Berbagai hasil penelitian menunjukkan bahwa pembiayaan pendidikan pada masa pandemi Covid 19 sebagian besar berjalan dengan baik dengan adanya keberpihakan kebijakan dari pemerintahan melalui bantuan kuota internet, bantuan BOS afirmasi dan kinerja, beasiswa, subsidi upah, dan UKT di perguruan tinggi. Namun demikian, masih terdapat sekolah khususnya sekolah swasta yang mengalami kesulitan membayar honorarium guru, kesejahteraan guru menurun, dan pembayaran SPP oleh orang tua kurang lancar. Strategi solusi pembiayaan pendidikan pada masa pandemi Covid 19 adalah kebijakan pemerintah berupa bantuan kepada peserta didik dan orang tua perlu terus dilanjutkan, konsistensi perencanaan anggaran oleh sekolah, kebijakan penggunaan anggaran yang mengedepankan skala prioritas, dan adanya transparansi dan akuntabilitas dalam pengelolaan pembiayaan pendidikan.

\section{REFERENSI}

Ade Sopiali. (2018). Teori dan Konsep Dasar Pembiayaan (Cost) dalam Pendidikan Islam (Rencana, Organisasi, Pelaksanaan, dan Pengawas. Jurnal Inteligensia, 06(2), 103-118.

Adianto Asdi Sangki, Ronny Gosal, J. K. (2017). Penerapan Prinsip Transparansi dan Akuntabilitas dalam Pengelolaan Anggaran Pendapatan dan Belanja Desa (Suatu Studi Di Desa Tandu Kecamatan Lolak Kabupaten Bolaang Mongondow). Jurnal Eksekutif, 1(1).

Aji, R. H. S. (2020). Dampak Covid-19 pada Pendidikan di Indonesia: Sekolah, Keterampilan, dan Proses Pembelajaran. SALAM: Jurnal Sosial Dan Budaya Syar-I, 7(5), 395-402. https://doi.org/10.15408/sjsbs.v7i5.15314

Alawiyah, F. (2017). Standar nasional pendidikan dasar dan menengah. Aspirasi, 8(1), 81-92. https://jurnal.dpr.go.id/index.php/aspirasi/article/view/1256

Amalia, A., \& Sa'adah, N. (2020). Dampak Wabah Covid-19 Terhadap Kegiatan Belajar Mengajar Di Indonesia. Jurnal Psikologi, 214-225. https://doi.org/10.35760/psi.2020.v13i2.3572

Endrianti, R. D. dan N. L. (2016). Pengelolaan Keuangan Keluarga Secara Islam pada Keluarga Muslim Etnis Padang dan Makasar di Surabaya. Jurnal Ekonomi Syariah Teori Dan Terapan, 3(7), 549-560.

Fironika K, R. (2015). Pembiayaan Pendidikan Di Indonesia. Jurnal Pendas, 2(1), 43-64.

Kharisma, B. (2018). Perencanaan, Penganggaran dan Capaian Target Program Wajib Belajar 12 Tahun : Kasus di Kabupaten Bogor dan Kabupaten Bandung. E-Jurnal Ekonomi Dan Bisnis Universitas Udayana, 9(21), 1-9.

Kurniawan, L. Y. (2019). Konsep Dasar Pembiayaan Pendidikan. https://doi.org/10.31227/ osf.io/4ztcq 
Lindawati, S. (2016). Penggunaan Metode Deskriptif Kualitatif Untuk Analisis Strategi Pengembangan Kepariwisataan Kota Sibolga Provinsi Sumatera Utara. Seminar Nasional APTIKOM (SEMNASTIKOM), Hotel Lombok Raya Mataram, 833-837.

Margareta, R. T. E., \& Ismanto, B. (2017). Strategi Perencanaan Pembiayaan Sekolah dalam Peningkatan Mutu di SMP Negeri. Kelola: Jurnal Manajemen Pendidikan, 4(2), 195. https://doi.org/10.24246/j.jk.2017.v4.i2.p195-204

Masruri, M., Ali, H., Rosadi, K. I., Islam, U., Sultan, N., Jambi, T. S., Islam, U., Sultan, N., Saifuddin, T., Islam, U., Sultan, N., \& Saifuddin, T. (2021). Pengelolaan Keuangan Dalam Mempertahankan Kualitas Pondok Pesantren Selama Pandemi Covid 19. Jurnal Ilmu Manajemen Terapan, 2(5), 644-657.

Maulan Irwadi. (2015). Analisis Anggaran Kas Sebagai Alat Perencanaan dan Pengendalian pada Koperasi KOPDIT RUKUN Palembang. Jurnal Akuntansi Politeknik Sekayu, 151(2), 10-17.

Permendikbud. (2020a). Peraturan Menteri Pendidikan dan Kebudayaan. Kebijakan Bantuan Operasional Sekolah Afirmasi Dan Kinerja, 23, 580, 5.

Permendikbud. (2020b). Peraturan Menteri Pendidikan dan Kebudayaan. Kemendikbud, No 24 dan.

Permendikbud. (2020c). Peraturan Menteri Pendidikan dan Kebudayaan Nomor 25 tahun 2020 tentang standar satuan biaya operasional pendidikan tinggi. Standar Satuan Biaya Operasional Pendidikan, 25.

Permendikbud. (2021). Peraturan Menteri Pendidikan dan Kebudayaan. Kemendikbud, 32.

Permendiknas. (2003). Peraturan Pemerintah tentang Pendanaan Pendidikan Nomor 20 tahun 2003. Kemendiknas.

Permendiknas. (2008). Peraturan Pemerintah tentang Pendanaan Pendidikan. Kemendiknas, 48.

Permendiknas. (2013). Peraturan Menteri Pendidikan Nasional tentang Standar Pembiayaan Pendidikan. Peraturan Menteri Pendidikan Nasional Republik Indonesia No.32 2013.

Sayuti, R. H., \& Hidayati, S. A. (2020). Dampak Pandemi Covid-19 Terhadap Ekonomi Masyarakat di Nusa Tenggara Barat. RESIPROKAL: Jurnal Riset Sosiologi Progresif Aktual, 2(2), 133-150. https://doi.org/10.29303/resiprokal.v2i2.46

Siantoro, A., Prihadi, C., Tambunan, E., \& Malino, T. (2020). Pandemi COVID-19 dan Pengaruhnya Terhadap Anak Indonesia : Sebuah Penilaian Cepat Untuk Inisiasi Pemulihan Awal. 1-16.

Sobana. (2020). Dampak Pandemi Covid 19 Terhadap Pendidikan dan Pelatihan Aparatur. Jurnal Pendidikan Indonesia, 1(2), 166-175. https://doi.org/10.36418/japendi.v1i2.18

Solihat, E., \& Sugiharto, T. (2009). Pengaruh Transparansi Dan Akuntabilitas Pengelolaan Pendidikan Terhadap Partisipasi Orangtua Murid Di Sma Negeri 107 Jakarta. Jurnal Ilmiah Ekonomi Bisnis, 14(2), 5904. https://doi.org/10.35760/eb.

Suhirman. (2012). Pengaruh Biaya Pendidikan Terhadap Hasil Belajar Melalui Proses Belajar Mengajar Di Sma Negeri Se-Kabupaten Rembang Tahun 2011. The Journal of Economic Education, 1(2), 117-122. 
Tamam, B. (2018). Reorientasi Pendanaan Pendidikan dalam Membangun Mutu Sekolah. Misykat Al-Anwar Jurnal Kajian Islam Dan Masyarakat, 29(2), 35-42. https://jurnal.umj.ac.id/ index.php/MaA16/article/view/2855

Utama, D. A. \& R. S. (2014). Pengaruh Transparansi, Akuntabilitas, Dan Responsibilitas Pengelolaan Keuangan Sekolah Terhadap Kinerja Guru. Dinamika Pendidikan Unnes, 9(2), 100-114. https://doi.org/10.15294/dp.v9i2.4886

Waliyah, S., Dini, S. H., \& Syarif, A. (2021). Manajemen Pembiayaan Pendidikan Masa Pandemi Covid-19 di SMK Gazza Wiguna 1 PENDAHULUAN Lembaga sebuah pendidikan memiliki sebagai fungsi keluar sebagai lembaga pelayanan pendidikan berfungsi memberikan bekal berbagai kemampuan bagi peserta didik secara $k .1(1), 77-98$. 